\title{
Impact of Tangible and Intangible Rewards on Organizational Commitment: Evidence from the Textile Sector of Pakistan
}

\author{
Shahnawaz Saqib1', Muhammad Abrar², Hazoor Muhammad Sabir', Mohsin Bashir ${ }^{1 *}$, \\ Sajjad Ahmad Baig2 \\ ${ }^{1}$ Department of Business Administration, GC University, Faisalabad, Pakistan \\ ${ }^{2}$ Department of Business Administration, National Textile University, Faisalabad, Pakistan \\ Email: ${ }^{*}$ mohsinhust@gmail.com
}

Received 27 February 2015; accepted 23 March 2015; published 27 March 2015

Copyright (C) 2015 by authors and Scientific Research Publishing Inc.

This work is licensed under the Creative Commons Attribution International License (CC BY). http://creativecommons.org/licenses/by/4.0/

c) (i) Open Access

\section{Abstract}

This study explores the relationship between tangible rewards, intangible rewards and organizational commitment with the mediating role of collectivism in the textile sector of Pakistan. In total, 250 questionnaires were distributed. The response rate was $81 \%$. Data were analyzed by using SPSS (20.0) software. Results showed that collectivism was negatively correlated with tangible and intangible rewards and positively correlated with organizational commitment. Further results showed that tangible and intangible rewards had a significant impact on the organizational commitment. Moreover, mediating role of collectivism has also been proved. Theoretical \& managerial implications, recommendations and limitations for future research have been discussed.

\section{Keywords}

Tangible Rewards, Intangible Rewards, Organizational Commitment, Collectivism, Motivation

\section{Introduction}

A well-established reward and recognition system is necessary to produce desired level of motivation in the employees. Both tangible and intangible rewards help an organization to enhance the motivational level of the employees. But a balance between tangible and intangible rewards should be made by the organizations as per demands of the employees, as out dated, unrealistic, less meaningful, complicated, and irrelevant items will result in demotivation of employees [1].

\footnotetext{
*Corresponding author.
}

How to cite this paper: Saqib, S., Abrar, M., Sabir, H.M., Bashir, M. and Baig, S.A. (2015) Impact of Tangible and Intangible Rewards on Organizational Commitment: Evidence from the Textile Sector of Pakistan. American Journal of Industrial and Business Management, 5, 138-147. http://dx.doi.org/10.4236/ajibm.2015.53015 
Intrinsic factors (monitory rewards) like pay, bonuses and promotions have their own importance in motivating the employees. No doubt money is the primary factor in motivation of employees, but on the other hand intrinsic (non-monitory) recognitions like appreciation, simple thank you, delegation of authority, long service certificate, employee of the month/year, use of recreational facilities, an outdoor day, gifts and voucher systems have also a vital role in the motivation of employees and increase in the performance of organization. Individuals have personal characteristics according to which they believe as per their own value what is important to them [2].

[3] argued that by following best human resource practices, organizations can change the behaviors of employees to create loyalty with the organization. Motivation of a worker will lead towards the desire of commitment with the organization.

As element of financial rewards brings the motivation in the employees on one side, then the non-financial awards are also a resource of motivation for the employees and cost effective for the organizations. A development of just "Thank You” culture within the organization will bring a good change in the behavior of employees towards creating loyalty [1].

[4] defined motivation as a force which was generated in an employee due to internal and external factors. This energetic force leads towards commitment with the work and work-related behavior is generated. Further this force also describes the magnitude of work-related behavior. Therefore it is crucial for the managers to find the particular forces that can maximize the work-related behavior of their employees. Employee motivation contributes an important role in overall success of every organization. Organizational commitment is linked to satisfaction and motivation [5]. This link of motivation and satisfaction can increase the productivity and organizational effectiveness.

The energy crisis in Pakistan has brought a drastic change in the performance of textile sector. The products of the textile sector constitute the major portion of exports of Pakistan economy. The textile sector holds a pivotal role in the development of Pakistan Economy being the backbone of economy as Pakistan is included in the 5 largest cotton producers of the world [6]. During this downtime of textile sectors, the organizations are struggling to survive and now more vigilant about human resource management issues.

The threat of job security has become a major source of demotivation among the employees whereas organizations are considering the cost effective plans to increase the productivity by creating job commitment. Organizations cannot achieve the desired results without considering the strategic alignment between the organizational goals and reward and recognition system by creating job commitment.

\section{Review of Literature}

[7] found positive and significant relationship between the financial compensation and level of motivation of employees of nonprofit organizations of Pakistan. [8] conducted survey on the reward \& recognition system of Australia \& New Zealand. Report showed that mostly people are motivated or want to be recognized with spending time, doing activities and sharing experiences with friends and family. Rewards and recognition act as a reminder for them about special achievements and it becomes a source of encouragements to repeat the efforts in future. The frequency of rewards and recognitions assures employees that they have worth and organizations value them [9].

[10] argued that organizations having a balance between extrinsic and intrinsic reward will show better performance. Employees should not be recognized on occasion's basis but they should also be recognized on daily basis. This will communicate a positive impact in the mind of employees that they are valued and trusted and respected. Salary is the most important part of the reward system, but non monitory rewards are perceived more important by the employees on daily work and it is needed that monitory and non-monitory rewards should go side by side.

[11] argued that commitment depends upon the on rewards and recognition offered by the organization. According to [12] the motivation of employees can be increased by offering better reward and recognition programs and these reward and recognitions programs will enhance the efficiency of the organization. The success of any organization depends upon the way in which it motivates its worker. Literature revealed that the motivated and satisfied individuals will retain themselves with the organizations which ultimately reduce the hiring cost [13]. Companies with reward and recognition programs outperform their competitor, further customer satisfaction; loyalty and profitability are tied to recognitions [14]. 
[15] stated that success of any organization can be measured by the human resources as how they are being considered. By following a good and balanced reward and recognition systems, organizations have made a progress. Performance of motivated and satisfied worker has a direct impact on the success of organization. Under demoted circumstances the performance of the employees is not up to the mark. Demotivated employees cannot exert their efforts with full spirit.

Better working conditions and reasonable rewards and recognition programs motivate employees to perform in well manner. Offering reward and recognition to the employees make them sure that they are being valued by the organization. These feelings will boost employee's motivation and thus increases productivity of organizations [16]. Effective rewards and recognition programs boost the morale of employees and develop a relationship between performance and motivation of the individuals [17].

[18] argued that intrinsic motivation is measured through feeling of autonomy. In this regard, other studies have concluded that intrinsic motivation includes a feeling of competence which can be raised by positive performance feedback; and on the other hand, can be declined by a negative performance feedback. To attain that level supervisors should give protection, coaching, guidance, instruments, and all other needed resources to ensure that knowledge and development is being managed.

Rewards and recognitions program create job satisfaction. This job satisfaction is positive feeling about the work experience. The ultimate purpose of rewards and recognition is to keep the individuals committed and motivated. In today's dynamic environment non-financial or intangible rewards are also the need of employees, as only monitory compensation cannot increase the motivational level of the employees to keep them committed and satisfied [19]. According to [20] the fringe benefits are most motivating rewards for employees. [21] investigated the consequences of tangible rewards on the quality of work of organizations providing medical facilities to the people and found that tangible rewards have positive impacts. [22] argued that motivation helps to maintain better relationship between the management and workers. The strength of any organization depends upon the relationship between the employees and their supervisors. Supervisors have effect on motivation and satisfaction of employees. [23] stated that intangible rewards give long term motivation to the employees.

Motivation and job satisfaction go side by side. Feedback and challenging work tasks are the two things which most effect the motivation and satisfaction. Career opportunities and appraisal systems are also the factors which influence the motivation of workers. Employees who don't have the wish to become a manager are got dissatisfied [24].

Non-financial rewards increase the working life of individuals). Intentions are the drivers of motivation [25]. The researcher should consider the outcomes that the rewards may cause for both employee and employer. To redefine intrinsic rewards, remember that they exist in the job itself like satisfaction of being prosperous in performing a task, appreciation from the management, and autonomy; whereas extrinsic rewards are tangible in nature like pay, fringe benefits, bonuses, and promotions [26].

Rewards and recognition depends upon different factors ranging from demographic variables (gender, age, culture, society) to personal tendencies like individual goals, psychological and physiological needs. This motivation is vital for the individuals and the organizations. It can be added here that individuals hold vital place in any organization therefore they should be treated in good way so that they can contribute for the betterment of organizations. Organizations always face a challenge to adopt the policies according to the change in markets and employee's needs. Thus, the managers have huge responsibilities to improve and arrange these relations to act powerfully in the market in which the strategies and the composition of organizations have changed a lot. Tangible and intangible rewards contribute too much to increasing the performance [27].

[28] argued that there is a significant relationship among tangible \& intangible rewards and organizational performance. This study further proved that tangible rewards have more impact on motivation as compared to non-financial or intangible rewards.

According to [29] Al-Angari (1999), non-financial incentives mostly affect the performances of employees. The impact of non-financial compensation to satisfy the employees is not too much. Rewards which are most valuable for the individuals are promotions, monitory allowances, leaves, medical facilities and involvement in decision making process. Rewards which are less considered by individuals are verbal appreciation and monitory payments for work at isolated \& remote places. Most valued incentives among all are financial. Intangible or non-financial rewards are also effective and increase the job performance and satisfaction [30].

[31] investigated to find the employee's opinion regarding valuing the rewards. As per findings of study no distinguishable variation in the opinions of employees was found and all employees argued that financial com- 
pensation \& promotion are most valuable for them.

Rewards are positively associated with the motivation. According to [15], employees value rewards on the basis of amount of reward which is given and weightage that an individual imparts to reward. Motivated and satisfied employees perform better when they feel satisfied with the job. In the dynamic environment financial and no financial compensations are the fundamentals of any motivational program. [32] argued that providing promotional opportunities will affect the personal growth and an increase on social standing.

There is considerable link between financial and non-financial compensation, motivation and job satisfaction. If magnitude of financial and non-financial rewards is altered then the level of motivation and satisfaction also changes with it [33]. A clear reward system includes an obvious communication of the offer and concentration on the rewards as well as the concerns about comprehending the methodologies, targets, and measures applied while introducing rewards. Under this situation employees need to know the relationship between firm's goals, their supply, and the way they are rewarded; and if there is ambiguity in this communication then it will reduce the level of motivation and value of reward [34].

Study of organizational commitment has proved that commitment comes from attitudinal, behavioral and motivational prospective. [35] categorized the mind sets into three categories, affective commitment, continuous commitment and normative commitment. Affective commitment is considered as the desire to attach with the present employer on the basis of emotions, continuous commitment refers to the need of being attached with the organization keeping in view the economic costs of leaving the organization and third component describes the moral obligations to be attached with the organization i.e. normative commitment.

Affective commitment or desire based commitment arises when an individual becomes involve or identifies his value within the organization, continues commitment develops when individual perceive that cost of leaving the organization is high and there are minimum alternatives available to them. Normative commitment develops due to social norms which bind individual with the organization in psychological contract [36].

[35] argued that each component of organizational commitment is affected by various factors. As affective commitment is influenced by work experience, Continues commitment is affected by perception regarding cost of leaving the organization and normative commitment is affected by the social factors. [37] argued that individuals will have higher level of affective commitment if they are treated with consideration. Three components of commitment are not same. Studies have shown that individuals with higher level of affective commitment performs very well against the individuals which have low level of affective commitment. Individuals with high normative commitment outperform other and similarly employees who avoid losing the benefits/value try to remain attached with the organization [38] [39].

[40] argued that organizational commitment is the tendency of employee's identification \& involvement with workplace. Affective commitment can be increased by positive feedback from the supervisors [41]. Salary and commitment are positively co-related with each and other [42].

\subsection{Hypothetical Framework}

Hypothetical framework for the study is as under:

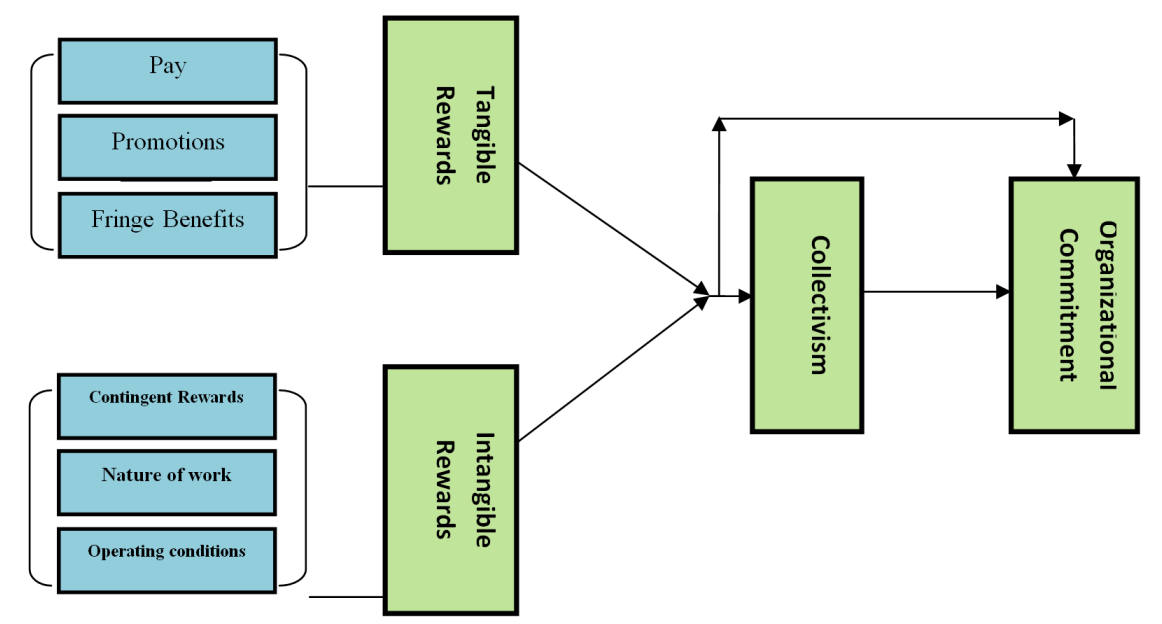




\subsection{Hypothesis}

On the basis of literature support followings hypothesis were formulated:

H1: Tangible rewards have positive impact on organizational commitment.

H2: Intangible rewards have positive relationship with organizational commitment.

H3: Tangible and intangible rewards have positive relationship with organizational commitment.

H4: Collectivism mediates the relationship between tangible rewards and organizational commitment.

H5: Collectivism plays mediating role between the relationship of intangible rewards and organizational commitment.

\section{Methodology}

The research was conducted among the employees of textile sector of Faisalabad, Pakistan. Total 250 questionnaires were distributed, out of which 203 were received back with response rate of 81 percent. Participants were workers, junior level manager, middle level manager and senior level manager. Mean and standard deviation have been find out by descriptive statistics for obtaining information normality. Means describes the average reaction from the workers while standard deviation is found out to check the variation within the information that what lengths aside the information values tend to be in the mean. Pearson correlation analysis was used to find out the relationship between variables. The positive sign of correlation value describes a good relationship with one of the parameters as well as a negative indication represents the negative relationship. The change in the dependent variable has been studied by regression analysis. Simple and multiple regression analysis have been carried out by Software (SPSS 20.0). Cronbach's alpha has been used to measure the reliability of the scales.

\subsection{Instrument}

Organizational commitment is the topic which has been studied extensively. Different factors affect the attachment with the organizations. Out of which are tangible and intangible rewards (financial and non-financial incentives). Different relevant literature was explored pertaining to international and national level for the development of questionnaire. Well established and authentic questionnaires were followed to develop the instrument. Five-point (1-5) likert scale instrument (strongly agree to strongly disagree) was used. Negative/reverse coded questions were also used in the instrument so that the respondents may answer with care and more meaningful response. The instrument comprises upon the following portions.

\subsubsection{Independent Variables}

Different tools are available for the measurement of job satisfaction with tangible and intangible rewards (financial Incentives) [43]. JSS was used to measure the satisfaction. Although this JSS was originally developed for use in human service organizations, it can be used for any type of organization. This tool contains 36 items, with 9 sub scales to measure the employee behaviors regarding the job itself and various aspects of job. Each subscale consists 04 questions. 06 sub scales were used for the measurement of satisfaction with tangible $\&$ intangible rewards.

\subsubsection{Mediating Variable}

Collectivism/individualism was measured through [44] 06 item cultural scale. Internal consistency for this item was calculated to test the reliability of scale.

\subsubsection{Dependent Variable}

A variety of instrument is available to measure the organizational commitment. Investigating the literature it has been found that mostly used instrument is [45]. In present study [45] OCQ was used to measure the organizational commitment among the employees.

\subsection{Instrument Reliability}

Commonly used statistical tool for the reliability of instrument/scales is Cronbach's coefficient alpha. By using SPSS (20) Cronbach's alpha reliability coefficients of each variable was calculated. 


\section{Results}

\subsection{Descriptive Statistics}

Table 1 shows mean, standard deviation and Cronbach’s alpha for the independent, dependent and mediating variables.

\subsection{Correlation Analysis}

Table 2 shows the correlation analysis of independent, dependent \& mediating variables.

Pearson correlation for the independent, dependent and mediating variables was calculated by using SPSS. To claim a mediating relationship, first there should be significant relationship between the independent variables, dependent variable and the mediator. First condition of [46] is satisfied.

\subsection{Regression Analysis}

Simple and multiple regression analysis along with hierarchal regression analysis were used test the impact of independent variables (tangible and intangible rewards) on dependent variable (organizational commitment) with the mediating effect of mediator (collectivism). The impact of tangible rewards on organizational commitment is shown in Table 3. Similarly the impact of intangible rewards is shown in Table 4. The collective impact of tangible \& intangible rewards has been shown in Table 5. Regression model of Table $3\left(\mathrm{R}^{2}=0.259, \mathrm{~F}=\right.$ 71.092, Sig = 0.000), 4.4 $\left(\mathrm{R}^{2}=0.243, \mathrm{~F}=65.513\right.$, Sig = 0.000 $) \& 4.5\left(\mathrm{R}^{2}=0.290, \mathrm{~F}=41.950, \mathrm{Sig}=0.000\right)$ and positive value $\beta$ depicts that there is positive and significant relationship between tangible and intangible rewards and organizational commitment.

Hence H1, H2 \& H3 accepted.

\subsection{Mediation Analysis}

As per requirement of Baron \& Keny (1996) the path between independent variables and mediating variable must be significant. Table 6 and Table 7 (Regression analysis) show that collectivism partially mediates the relationship between tangible rewards and organizational commitment leading us towards the acceptance of H4. Furthermore due to insignificant impact of intangible rewards on mediating variable the relationship between intangible rewards and organizational commitment was not possible to check in the textile sector of Pakistan (Table 6 and Table 7).

\section{Table 1. Descriptive statistics.}

\begin{tabular}{cccccc}
\hline & \multicolumn{5}{c}{ Descriptive statistics } \\
\hline & $\mathrm{N}$ & Mean & Std. deviation & No. of items & Alpha \\
\hline Tangible rewards & 202 & 2.7776 & 0.47552 & 12 & 0.80 \\
Intangible rewards & 202 & 2.5860 & 0.37224 & 12 & 0.71 \\
Organizational commitment & 202 & 2.5287 & 0.27237 & 15 & 0.56 \\
Collectivism & 202 & 2.0396 & 0.43458 & 6 & 0.85 \\
\hline
\end{tabular}

Table 2. Correlation table.

\begin{tabular}{|c|c|c|c|c|c|}
\hline & \multicolumn{5}{|c|}{ Correlations } \\
\hline & Variable & 1 & 2 & 3 & 4 \\
\hline 1 & Tangible rewards & 1 & & & \\
\hline 2 & Intangible rewards & $0.718^{* * *}$ & 1 & & \\
\hline 3 & Collectivism & $-0.142^{* *}$ & $-0.113^{*}$ & 1 & \\
\hline 4 & Organizational commitment & $0.512^{* * *}$ & $0.497^{* * *}$ & $0.145^{* * 1}$ & \\
\hline
\end{tabular}

\footnotetext{
${ }^{* * *}$ Correlation is significant at the 0.01 level (2-tailed). ${ }^{* *}$ Correlation is significant at the 0.05 level (2-tailed). ${ }^{*}$ Correlation is significant at the 0.10 level
} (2-tailed). 


\section{Discussion \& Conclusion}

The purpose of this study was to investigate the relationship between the tangible, intangible rewards and organizational commitment as well as to test the mediating role of collectivism between the rewards and organizational commitment. The empirical results supported the relationship between the tangible rewards and organizational commitment. Second, the relationship between the intangible rewards and organizational commitment has also been supported by the results. Third, the collective and positive impact of tangible and intangible rewards on the organizational commitment has also been proved by the empirical results. These findings proved that rewards had a positive and significant impact on the organizational commitment in textile sector of Pakistan at Faisalabad. These finding are in connection with the literature. As per study conducted by [8] on the reward \& recognition system of Australia \& New Zealand, mostly people are motivated or want to be recognized with spending time, doing activities and sharing experiences with friends and family. Rewards and recognition act like reminder for the employees about special achievements and it becomes a source of encouragements to repeat the efforts in future. The frequency of rewards and recognitions assures employees that they have worth for organizations [9]. These finding are also in connection with the findings of [29] that non cash rewards have an effect on the performances of individuals.

\subsection{Theoretical \& Managerial Implications}

From above conclusions, it is recommended that organizations have to align their tangible and intangible rewards. The balance between financial and non-financial rewards is necessary to maintain and boost the level of job satisfaction and motivation in order to increase the organizational commitment. This will increase the loyalty of the employees. Results due to higher level of loyalty will be beneficial for the organizations in various aspects.

Table 3. Regression analysis: tangible rewards as independent variable.

\begin{tabular}{ccccc}
\hline Dependent & Independent & $\beta$ & $\mathrm{t}$ & Sig \\
\hline $\begin{array}{c}\text { Organizational } \\
\text { commitment }\end{array}$ & Tangible rewards & 0.512 & 8.432 & 0.000 \\
\hline
\end{tabular}

Table 4. Regression analysis: intangible rewards as independent variable.

\begin{tabular}{ccccc}
\hline Dependent & Independent & $\beta$ & $\mathrm{t}$ & Sig \\
\hline $\begin{array}{c}\text { Organizational } \\
\text { commitment }\end{array}$ & Intangible rewards & 0.497 & 8.094 & 0.000 \\
\hline
\end{tabular}

Table 5. Regression analysis: tangible \& intangible rewards as independent variables.

\begin{tabular}{ccccc}
\hline Dependent & Independent & $\beta$ & $\mathrm{t}$ & Sig \\
\hline $\begin{array}{c}\text { Organizational } \\
\text { commitment }\end{array}$ & Tangible rewards & 0.321 & 3.755 & 0.000 \\
\hline
\end{tabular}

Table 6. Regression analysis: tangible rewards as independent variable.

\begin{tabular}{ccccc}
\hline Dependent & Independent & $\beta$ & $\mathrm{t}$ & Sig \\
\hline Collectivism & Tangible rewards & -0.142 & -2.030 & 0.044 \\
\hline
\end{tabular}

Table 7. Regression analysis: collectivism as mediating variable.

\begin{tabular}{cccccc}
\hline Model & Dependent & Independent & $\beta$ & $\mathrm{t}$ & \\
\hline 1 & $\begin{array}{c}\text { Organizational } \\
\text { commitment }\end{array}$ & Tangible rewards & 0.512 & 0.432 \\
& Organizational & Tangible rewards & & \\
2 & commitment & collectivism & 0.544 & 0.143 \\
& & & 0.222 & 3.736 \\
\hline
\end{tabular}


It will reduce the absenteeism level on one side, and on the other hand performance level of employees will be enhanced. Similarly the turnover will be reduced and it will be beneficial for the organizations. This reduction in turn over will save the organizations from the cost of recruiting, selection and training. It will provide economic benefits to the organization. This economic benefit will have a greater worth when the organizations are under the financial crunches. This will enable them to cut down the unnecessary cost enabling them to move on the path of glorious success. In this way, they will better perform when others will be facing problems during economic down time. HR professionals can formulate strategies to achieve their objectives of maintaining high levels of employee motivation and creating organizational commitment to enjoy overwhelming performance during the financial crunches.

\subsection{Limitations and Suggestions for Future Research}

The study was conducted during the economic stress and energy crises. Due to these reasons, the textile sector of Pakistan was struggling very hard to survive. To gain deeper insight of the problem, it would be interesting and worthwhile that a quantitative study with large sample size is conducted to obtain more concrete insights regarding impact of tangible and intangible rewards on the organizational commitment with the mediating impact of collectivism in the public and private sector.

\section{References}

[1] Daniel, T.A. and Metcalf, G.S. (2005) The Fundamentals of Employee Recognition. Society of Human Resource Management.

[2] Armstrong, M. (2009) Handbook of Human Resource Management. 11th Edition.

[3] Arthur, J.B. (1994) Effects of Human Resource Systems on Manufacturing Performance and Turnover. Academy of Management Journal, 37, 670-687. http://dx.doi.org/10.2307/256705

[4] Pinder, C.C. (1984) Work Motivation; Theory, Issues, and Applications. Foresman and Company, Glenview.

[5] Yousef, D.A. (2000) Organizational Commitment: A Mediator of the Relationships of Leadership Behavior with Job Satisfaction and Performance in a Non-Western Country. Journal of Managerial Psychology, 15, 6-24. http://dx.doi.org/10.1108/02683940010305270

[6] (2013) www.wikipedia.com

[7] Zaman, K. (2011) Relationship between Rewards and Employee Motivation in the Nonprofit Organizations of Pakistan. Business Intelligence Journal, 4, 327-334.

[8] (2009) Reward \& Recognition Survey Results, Red Balloon for Corporate, Australia \& New Zealand.

[9] Shoib, M., Noor, A., Tirmizi, S.R. and Bashir, S. (2009) Determinants of Employee Retention in Telecom Sector of Pakistan. Proceedings of the 2nd CBRC, Lahore, 14.

[10] Silverman, M. (2004) Non-Financial Recognition, the Most Effective of Rewards. Institute for Employment Studies.

[11] Andrew, D.P.S. and Kent, A. (2007) The Impact of Perceived Leadership Behaviors on Satisfaction, Commitment, and Motivation: An Expansion of the Multidimensional Model of Leadership. International Journal of Coaching Science, 1, 35-56.

[12] Deeprose, D. (1994) How to Recognize and Reward Employees. AMACOM, New York.

[13] Csikszentmihalyi, M. (1990) Flow: The Psychology of Optimal Experience. Springer, Dordrecht.

[14] Employee Recognition and Reward Can Generate Significant Revenue and Profits. Recognition Council, 04.07.09.

[15] Lawler, E.E. (2003) Treat People Right. Jossey-Bass Inc. and McGraw-Hill Irwin, San Francisco.

[16] Freedman, M.S. (1978) Some Determinants of Compensation Decisions. The Academy of Management, 21, $397-409$.

[17] Flynn, G. (1998) Is Your Recognition Program Understood? Workforce, 77, 30-35.

[18] Ryan, R.M. and Deci, E.L. (2000) Intrinsic and Extrinsic Motivations: Classic Definitions and New Directions. Contemporary Educational Psychology, 25, 54-67.

[19] La Motta, T. (1995) Recognition: The Quality Way. Quality Resources, New York.

[20] Arnolds, C.A. and Venter, D.J.L. (2007) The Strategic Importance of Motivational Rewards for Lower-Level Employees in the Manufacturing and Retailing Industries. SA Journal of Industrial Psychology, 33, 15-23.

http://dx.doi.org/10.4102/sajip.v33i3.390 
[21] McDonald, R., Harrison, S., Checkland, K., Campbell, S.M. and Roland, M. (2007) Impact of Financial Incentives on Clinical Autonomy and Internal Motivation in Primary Care: Ethnographic Study. British Medical Journal, 334, 1357. http://dx.doi.org/10.1136/bmj.39238.890810.BE

[22] Morris, M. (2004) The Public School as Workplace: The Principal as a Key Element in Teacher Satisfaction. California University, Los Angeles.

[23] Lorinda, E. and Steuart, P. (2004) Should Leaders Have Tusks or Fangs? Management Today, 20, 32-33.

[24] Oztopark, T. and Lundmark, R. (2007) Reward \& Recognition Strategies: A Case Study of GE Healthcare in Umea.

[25] Shajahan, D.S. and Shajahan, L. (2004) Organization Behavior. New Age International Publications.

[26] Ajila, C. and Abiola, A. (2004) Influence of Rewards on Workers Performance in an Organization. Journal of Social Science, 8, 7-12.

[27] Alwabel, A. (2005) The Role of Financial and Moral Incentives on Raising the Performance Level of Employees from the Viewpoint of the Security Officers Involved in the Pilgrimage Season. Master's Thesis, Naif Arab University for Security Sciences, Riyadh.

[28] Al-Nsour, M. (2012) Relationship between Incentives and Organizational Performance for Employees in the Jordanian Universities. International Journal of Business and Management, 7, 78-89.

[29] Al-Angari Abdulla bin Abdul Aziz bin Abdul Rahman (1999) Incentives System and Their Role in Promoting the Standard of Work Performance. Master’s Thesis, Naif Arab University for Security Sciences, Riyadh.

[30] Al-Wathnani Awadh Mohanned Gallab (1998) Impact of Incentives on the Efficiency of Work Performance and Job Satisfaction in Security Organizations. Master’s Thesis, Naif Arab University for Security Sciences, Riyadh.

[31] Al-Johani Abdullah bin Sulaman (1997) Evaluation of Incentive System According to Employees Opinion: A Field Study on Immigration Department at Jeddah. Master's Thesis, Naif Arab University for Security Sciences, Riyadh.

[32] Robbins, S.P. (2001) Organizational Behavior. 9th Edition, Prentice-Hall, Inc., New York.

[33] Ali, R. and Ahmed, M.S. (2009) The Impact of Reward and Recognition Programs on Employee's Motivation and Satisfaction: An Empirical Study. International Review of Business Research Papers, 5, 270-279.

[34] Gibbons, R. (1998) Incentives in Organizations. NBER Working Papers Series, Working Paper 6695, National Bureau of Economic Research, Cambridge, MA.

[35] Meyer, J.P. and Allen, N.J. (1991) A Three-Component Conceptualization of Organizational Commitment. Human Resource Management Review, 1, 61-89. http://dx.doi.org/10.1016/1053-4822(91)90011-Z

[36] Meyer, J.P. and Herscovitch, L. (2001) Commitment in the Workplace: Toward a General Model. Human Resources Management Review, 11, 299-326. http://dx.doi.org/10.1016/S1053-4822(00)00053-X

[37] De Cotiis, T.A. and Summers, T.P. (1987) A Path Analysis of a Model of the Antecedents and Consequences of Organizational Commitment. Human Relations, 40, 445-470. http://dx.doi.org/10.1177/001872678704000704

[38] Allen, N.J. and Meyer, J.P. (1996) Affective, Continuance, and Normative Commitment to the Organization: An Examination of Construct Validity. Journal of Vocational Behavior, 49, 252-276. http://dx.doi.org/10.1006/jvbe.1996.0043

[39] Allen, N.J. and Meyer, J.P. (2000) Construct Validation in Organizational Behavior Research: The Case of Organizational Commitment. In: Goffin, R.D. and Helms, E., Eds., Problems and Solutions in Human Assessment: Honoring Douglas N. Jackson at Seventy, Kluwer Academic Publishers, Boston. http://dx.doi.org/10.1007/978-1-4615-4397-8_13

[40] Mowday, R.T., Steers, R.M. and Porter, L.W. (1979) The Measurement of Organizational Commitment. Journal of Vocational Behavior, 14, 224-247. http://dx.doi.org/10.1016/0001-8791(79)90072-1

[41] Eisenberger, R., Fasolo, P. and Davis-LaMastro, V. (1990) Perceived Organizational Support and Employee Diligence, Commitment, and Innovation. Journal of Applied Psychology, 75, 51-59. http://dx.doi.org/10.1037/0021-9010.75.1.51

[42] Mathieu, J.E. and Zajac, D. (1990) A Review and Meta-Analysis of the Antecedents, Correlates and Consequences of Organizational Commitment. Psychological Bulletin, 108, 171-194. http://dx.doi.org/10.1037/0033-2909.108.2.171

[43] Spector, P.E. (1985) Measurement of Human Service Staff Satisfaction: Development of the Job Satisfaction Survey. American Journal of Community Psychology, 13, 693-713. http://dx.doi.org/10.1007/BF00929796

[44] Dorfman, P.W. and Howell, J.P. (1988) Dimensions of National Culture and Effective Leadership Patterns: Hofstede Revisited. Advances in International Comparative Management, 3, 127-150.

[45] Porter, L.W., Steers, R.M., Mowday, R.T. and Boulian, P.V. (1974) Organizational Commitment, Job Satisfaction, and Turnover among Psychiatric Technicians. Journal of Applied Psychology, 59, 603-609.

http://dx.doi.org/10.1037/h0037335 
[46] Baron, R.M. and Kenny, D.A. (1986) The Moderator-Mediator Variable Distinction in Social Psychological Research: Conceptual, Strategic, and Statistical Considerations. Journal of Personality and Social Psychology, 51, 1173-1182. http://dx.doi.org/10.1037/0022-3514.51.6.1173 